\title{
E-Business Initiatives in Indonesian Manufacturing SMEs
}

\author{
Singgih Saptadi ${ }^{*}$, Iman Sudirman², TMA Ari Samadhi², Rajesri Govindaraju²
}

\begin{abstract}
The role of information technology (IT) in improving companies' competitiveness, including small and medium enterprises (SMEs), has been widely accepted. But, the IT investment will be in vain, if SMEs do not align their business and IT. There is a need to develop a framework of business-IT alignment. The framework development requires an understanding of the patterns of IT implementation in supporting SMEs' business (e-business initiatives). This paper presents an empirical study on e-business initiatives in Indonesian manufacturing SMEs. The study uses 41 business processes that are grouped into three business focuses: supplier side, internal side and customer side. Based on the complexity of IT support to business processes, supplier side score, internal side score, customer side score and global score can be calculated. These scores are used to develop e-business initiative groups by using cluster analysis. After validated using discriminant analysis, the cluster analysis gives five e-business initiatives. First initiative is e-business implementation in three sides of business focuses, although in the early stage. Second initiative is IT implementation with internal side focus. Third initiative is ebusiness with customer side focus. The fourth is initiative that focuses on internal and customer side. The last is e-business initiative that balances and extends IT implementation on the three sides of business focuses. Then, this paper explains the differences between e-business initiatives.
\end{abstract}

Keywords: E-business, business process, small and medium enterprise, cluster analysis, business focus, functional activity.

\section{Introduction}

Small and Medium Enterprises (SMEs) provides lots of contributions in the Indonesia economic development. SMEs are productive economic activities with sales between 2.5 billion rupiahs to 50 billion rupiahs per year (Indonesia, [1]). SMEs have potential and strategic role as they have proved their contributions to national economic growth (progrowth) (Depkopukm, [2]). SMEs are the economic actors and the subject of national development, especially in the expansion of business opportunities for new entrepreneurs and in the reduction of unemployment (pro job) (Depkopukm, [2]). Therefore, improving the SMEs' competitiveness becomes the major concern of Indonesian government.

The role of technology, including IT, in supporting companies to improve their competitiveness has been highlighted by many researchers (Lefebvre et al. [3], Hamad [4]). IT, especially the internet, has become a resource in transforming the companies

\footnotetext{
${ }^{1}$ Faculty of Engineering, Department of Industrial Engineering, Universitas Diponegoro, Jl. Prof. Sudharto, Tembalang Semarang 50238, Indonesia. Email: singgihs@gmail.com

2 Faculty of Industrial Technology, Department of Industrial Engineering, Institut Teknologi Bandung, Jl. Ganesha 10 Bandung 40132, Indonesia

Email: imansudirman_itb@yahoo.com, arisamadhi@yahoo.com, rajesri_g@yahoo.com
}

*Corresponding author and increasing their competitiveness (Alam and Noor, [5] Porter [6], Laudon and Laudon [7]). IT shifts the product marketing paradigm from broadcast marketing to interactive marketing (Avlonitis and Karayanni, [8]; Gilmore et al. [9]). IT allows companies to interact with their suppliers and customers (Beach, [10]). As a low entry price technology, IT allows SMEs to grow and compete with large companies (Goode and Stevens, [11]; Moriones and Lopez [12]).

To improve SMEs' competitiveness, Indonesian government facilitates trainings for SMEs, including e-business trainings. In this paper, e-business is defined as IT implementation, especially internet technology, to support business activities. These business activities include communication, coordination and organization management (Laudon and Laudon [7]). Our previous study on e-business adoption by SMEs found that there are only small proportion (less than 10\%) of SMEs that continue to use e-business after e-business trainings (Saptadi et al. [13]). The main reason is the lack of SMEs' ability to align IT and their business (Saptadi et al. [14]). This means that SMEs need help to do business-IT alignment. Therefore, a framework of business-IT alignment is needed to help SMEs.

Since most SMEs do not clearly formulate their business strategy and IT strategy, it is difficult to identify business-IT alignment through business 
strategy and IT strategy. Therefore, to understand business-IT alignment in SMEs, the patterns of ebusiness implementation will be studied empirically. Then, the findings of these e-business initiatives will be associated with other aspects that are required in business-IT alignment. This paper presents the empirical findings of e-business initiatives of SMEs with some explanations on the differences among ebusiness initiatives. In other words, this paper discusses "What are e-business initiatives that are implemented by Indonesian manufacturing SMEs and how the differences among these initiatives are?"

E-business initiatives that are implemented by Indonesia SMEs are rarely investigated. Wahid and Iswari [15] examined the e-business implementation by 146 SMEs in Yogyakarta that engage in various sectors. From these SMEs, there are 87 SMEs $(59.6 \%)$ that have used computers (Wahid and Iswari, [15]). These SMEs have e-business initiatives that support the efficiency of their internal business processes. Dominantly, IT is used for reports typing (69\%), performing calculations (66.7\%) and other tasks by the use of information systems (58.6\%). Information systems (IS) that are widely run by SMEs are accounting IS (54.9\%), sales IS (50.9\%), and inventory IS (25.5\%). With similar methods in data collecting and analysis, Roosdhani et al. [16] conducted a research on e-business initiatives by SMEs in Jepara. Roosdhani et al. [16] found different results from what Wahid and Iswari [15] found.

Ministry of Cooperatives and SMEs did some researches on 115 SMEs that engage in the production of automotive parts ((21\%), crafts (44\%) and textiles (35\%) (Smecda [17]). SMEs have used IT for administration (63 SMEs), product design (38 SMEs), marketing (38 SMEs) and production (19 SMEs). The communication via e-mail with customers is more prominent (35 SMEs) than the communication with suppliers (23 SMEs) and the support to the company's internal activities (22 SMEs). Most SMEs uses internet primarily to search for business information, to promote their products (21 SMEs) and to conduct online transactions (9 SMEs).

Previous researches on e-business initiatives in Indonesia show the implementation of diverse ebusiness initiatives in SMEs. Each type of SMEs may have implemented different e-business initiative. Although these researches discuss IT implementation in business activities, but they have not discussed in detail how e-business is applied at the level of the SMEs' business processes. So that these researches have not revealed clearly the wide of ebusiness initiatives that have been implemented by
SMEs. Also, previous researches did not discuss the differences among the initiatives.

While previous researches looked at SMEs in various sectors and SMEs that have and have not implemented e-business, this study is more focused on manufacturing SMEs that have implemented ebusiness. Further, this study conducts a deeper analysis than previous studies by using business processes approach to identify e-business initiatives. The reason why this paper uses the business process approach and the explanation of this approach are described below.

\section{Methods}

\section{Business Process Approach}

IT contribution to firm performance has been the focus of many studies (Tallon et al. [18]; Rivard et al. [19]). In fact, there is a consensus that IT contributes to firm values whether it be financial (e.g., ROI), intermediate (e.g., process-related) or affective (e.g., perception-related) (Kohli and Grover [20]). Literatures that describe the contribution of IT to business can be classified into two categories: Production-economic based approach and business process approach (Zhu and Kraemer [21]). Production-economic based approach views IT implementation and business performance as the input-output relationships and some literatures in this stream are summarized in (Brynjolfsson and Yang [22], Ramdani [23]).

As Kauffman and Weill [24] suggest, in IT research, analysis of IT contribution to the business should be conducted at the technology's locus of impact in the organization. The business processes are viewed as the locus of impact of IT (Barua et al. [25], Zhu and Kramer [26]. Many literatures emphasize that the business value of IT is best observed on the level of business processes (Dohmen et al. [27]), because IT business values are created on this level (Barua et al. [25]).

From e-business perspectives, the evolution of organizations can be seen as how extensive of their business processes are supported by IT and the complexity of the implemented IT (Earl, [28], Magal et al. [29]; Levy and Powell [30]). Since the complexity of an innovation is already known to be an inhibiting factor to the innovation adoption (Sahin, [31]), IT implementation in the SMEs' business processes can be considered as a form of assimilation of IT knowledge and skills by SMEs (Elia et al. [32]).

Based on these reasons, this study does analysis on the level of business processes. This study borrows the typology of business processes that have been 
identified by Elia et al. [32]. The typology presents business processes that can be run electronically (supported by IT). Because there are context differrences between Canada and Indonesia, this study does not compare the findings of this study with Elia et al. [32].

To ensure the 36 business processes that are identified by Elia, et al. [32] can be utilized in this study, a qualitative study have been conducted by interviewing four manufacturing SMEs (Saptadi et al. [33]). This qualitative study shows that some business processes in Elia et al. [32] have been supported by IT and the typology is applicable for further studies.

This qualitative study finds that in addition to business processes identified by Elia et al. [32], there are five business processes in the finance area that have been executed by SMEs with IT support. Table 1 presents the typology of business proceeses that can be executed electronically. The entries of table 1 are the identification numbers of business processes. Figure 1 lists the business processes that are associated with these identification numbers. The business processes are classified based on six functional activities and three business focuses.

The number in parantheses after each business process in Figure 1 is the complexity weight of each business process. Elia et al. [32] give the complexity weight to each business process (business processes 1 to 36) corresponds to the relative degree of technological complexity. This weight is assessed between 0 and 10 by a panel of 12 independent experts who were familiar with the manufacturing context and with the business process involved. After two iterations in Delphi methods, consensus was reached. The complexity weight of the business processes in the finance area is assessed by 7 software developers who have experiences in software implementation in manufacturing SMEs. Using Delphi methods, consensus on the complexity weight was reached after two iterations.

This study adopts the calculation of complexity score of IT supported business processes that is developed by Elia et al. [32]. The calculation of the global score follows the following formula:

$\frac{\sum_{i=1}^{n} c_{i} \times B P_{i}}{\sum_{i=1}^{n} c_{i}} 100$

where $c_{i}$ is the level of complexity of business processes $i ; B P_{i}=0$ if the business process is not run electronically and $B P_{i}=1$ if the business process is run electronically. The supplier side score, the internal side score and the customer side score are calculated in the same way but only involve business processes in each business focus.

To generalize the results of the qualitative study, a quantitative study is conducted and this paper discusses the quantitative study. The quantitative study involves 41 business processes, which are 36 business processes of Elia et al. [32] and 5 business processes of the qualitative study (Saptadi et al. [33]). By using these business processes, e-business initiatives and the differences among the initiatives are identified.

\section{Research Methods}

Three steps are executed in this study. First, respondents answer a questionnaire containing questions about the business characteristics of SMEs and their business processes that are already supported by IT. Second, the collected data are processed using cluster analysis. The cluster analysis is conducted on SMEs' business processes that are supported by IT. This means SMEs are grouped into e-business initiatives. Third, this study identifies the differences among e-business initiatives. The identification of differences among e-business initiatives is conducted through the differences of SMEs' business characteristics in each e-business initiative. The business type, the company size and the business orientation of SMEs describe the characteristics of SMEs.

This paper follows the definition of SMEs that is given by Indonesian government. Small enterprise is an economically productive and independent enterprise, which is run by an individual or a business entity that is not a subsidiary or a branch company. A small enterprise is not owned, controlled, or a part, either directly or indirectly of medium or large

Table 1. Typology of business processes adapted from Elia et al. [32] and Saptadi et al. [33]

\begin{tabular}{|c|c|c|c|c|c|c|c|}
\hline & \multicolumn{6}{|c|}{ Functional activities } & \\
\hline & Product Design & Procurement & Production & Marketing & Distribution & Finance & \\
\hline Supplier Focus & $2,3,4$ & $\begin{array}{c}6,7,8,9,10,11 \\
12,13,14\end{array}$ & 20,21 & & 34 & 37 & Supplier side score Global Score \\
\hline Internal Focus & & & $15,16,17$ & 24 & 33,36 & $38,39,40,41$ & Internal side score \\
\hline Customer Focus & $1,3,5$ & & 18,19 & $\begin{array}{c}22,23,25,26, \\
27,28,29,30 \\
31,32\end{array}$ & 35 & 37 & Customer side score \\
\hline
\end{tabular}


enterprise and has net worth between fifty to five hundreds millions Rupiahs not including the land and buildings, or has annual sales between three hundreds to two thousands five hundreds millions Rupiahs. Medium Enterprise has a net worth between five hundreds to ten thousands millions Rupiahs not including the land and buildings, or have annual sales between two and half to fifty billions Rupiahs (Indonesia [1]).

\section{A. Product Design}

1. Transfer documents and technical drawings to customers $(2,33)$

2. Transfer documents and technical drawings to suppliers $(2,33)$

3. Integrate software supporting product design (e.g.: $\mathrm{CAD} / \mathrm{CAM})(5,58)$

4. Do collaborative on-line engineering with suppliers. $(6,00)$

5. Do collaborative on-line engineering with customers. $(6,00)$

B. Procurement/Purchasing

6. Seek out new suppliers $(1,25)$

7. Seek out products/services $(1,25)$

8. Buy products/services using electronic catalogs $(2,25)$

9. Buy products/services by electronic auction $(2,92)$

10. Buy products/services by issuing electronic calls for tenders. $(3,50)$

11. Place and manage orders with suppliers. $(3,00)$

12. Negotiate contracts (price, volume, etc.) with suppliers $(2,92)$

13. Make electronic payments to suppliers $(2,91)$

14. Access suppliers' product/service databases $(3,33)$

C. Production/Operations

15. Automate the production floor using a manufacturing execution system (MES) $(4,50)$

16. Integrate the MES into the management information system. $(5,08)$

17. Ensure the management of quality assurance using the management information system $(3,33)$

18. Allow customers to access the company's inventories $(4,50)$

19. Access customers' inventories. $(4,08)$

20. Allow suppliers to access the company's inventories. $(4,50)$

21. Access suppliers' inventories $(4,00)$

D. Sales/Marketing

22. Advertise the company and/or its products/services. $(1,50)$

23. Seek out new customers $(1,25)$

24. Convert information on products/services into digital form. $(2,27)$

25. Sell products/services using electronic catalogs. $(2,75)$

26. Sell products/services by electronic auction. $(3,42)$

27. Sell products/services by responding to electronic calls for tenders $(3,50)$

28. Negotiate contracts (price, volume, etc.) with customers $(3,00)$

29. Receive and manage customer orders $(2,55)$

30. Receive electronic payments from customers $(3,00)$

31. Access customers' product/service databases $(3,75)$

32. Offer customers after-sales services $(2,75)$

E. Distribution/Logistics

33. Automate distribution/logistics using a logistics execution system (LES). $(5,25)$

34. Allow distribution/transportation partners to access the information they need $(5,08)$

35. Optimize returns management ("reverse logistics"). $(5,67)$

36 . Track products (purchased and sold) during transporttation. $(4,42)$

F. Finance

37. Administrate business transactions $(3,00)$

38. Administrate debt $(3,00)$

39. Administrate receivables $(3,00)$

40. Account profit/loss $(3,00)$

41. Account the assets $(3,00)$

Figure 1. Business processes according to functional activities and their complexitiy weight adapted from Elia et al. [32] and Saptadi et al. [33].
Industrialization shifts the manufacturing industry to become the most contributing sector to the economies of Indonesia (BPS, [34]). Figure 2 presents the contribution of each sector to Indonesia Product Domestic Bruto and shows that manufacturing sector is the most contributing factor to Indonesia Product Domestic Bruto. Based on these, this paper focuses on manufacturing SMEs. Since there is a wide variety of manufacturing SMEs, this study focuses on wood and metal manufacturing SMEs that conduct their business in a business-to-business way (B-to-B manufacturing SMEs).

The unit of analysis in this study is a wood/metal manufacturing SME that has adopted e-business. It means this study focuses on the SMEs that have used IT in their business. Respondents are individuals who represent the SMEs and they may be the owner, the manager or the employee who understands the adoption of e-business in their company. The respondents are asked about the characteristics of their business and what business processes that are already IT supported. From all respondents, their business processes are grouped using cluster analysis to find the pattern of e-business initiatives.

As mentioned earlier, this study uses the 41 business processes that can be run electronically. Based on these business processes, the SMEs are grouped by two groupings. The first grouping is based on six functional activities, namely: Product Design, Procurement/Purchasing, Production/Operations, Sales/ Marketing, Distribution/Logistics and Finance. The second grouping is based on three business focuses: Supplier, Internal and Customer. The groupings are done by conducting cluster analysis.

Cluster analysis does not determine the required sample size (Hair et al. [35]). But, Dolnicar [36] and Mooi and Sarstedt [37] recommend the required sample size as $5 \mathrm{x} 2^{\mathrm{k}}$, with $\mathrm{k}$ is the number of discriminant variables. This study conducts two cluster analysis. First cluster analysis groups business processes based on the functional activities and this means that the number of dicriminant variables is the number of functional activities $(\mathrm{k}=6)$.

Second cluster analysis groups business processes based on the business focuses and the number of discriminant variables is the number of business focuses $(k=3)$. The required sample size is based on the bigger $\mathrm{k}$ between the two cluster analysis and this means $\mathrm{k}=6$. With $\mathrm{k}=6$, a total of $320\left(5 \times 2^{6}\right)$ data are needed to conduct the two cluster analysis. This quantity is acceptable for this study (Dolnicar [36]).

Data are collected through a survey of SMEs in Java. Since most of Indonesia SMEs (64\%) are located in Java island (Tanjung [38]), the result of 
this study will represent the e-business initiatives in Indonesian manufacturing SMEs. As Java has 6 provinces, this study collects data by conducting random, stratified and proportional sampling. According to Ministry of Industry, there are 8182 medium enterprises (MEs) and 53458 small enterprises (SEs). From these numbers, there are 2043 wood manufacturing SMEs and 1472 metal manufacturing SMEs that are already registered (Kemenperin [39]). Based on the proportion of wood and metal SMEs and the proportion of SEs and MEs, the required samples size for each province is calculated. Table 2 presents the detail of sample sizes for each province in Java.

\section{Results and Discussion}

\section{E-business Initiatives}

The cluster analysis is conducted to identify the ebusiness initiatives in Indonesian manufacturing SMEs. As mentioned earlier, this study does two cluster analysis, which are based on the functional activities and business focuses. But, the cluster analysis that is based on the functional activities presents a diffuse result. This does not allow the conclusion that the groups were formed. Then, this paper only discusses the cluster analysis based on business focuses.

Cluster analysis is often conducted in two steps (Burns and Burns, [40]). The first step is a cluster analysis that uses Ward's method which is one of the

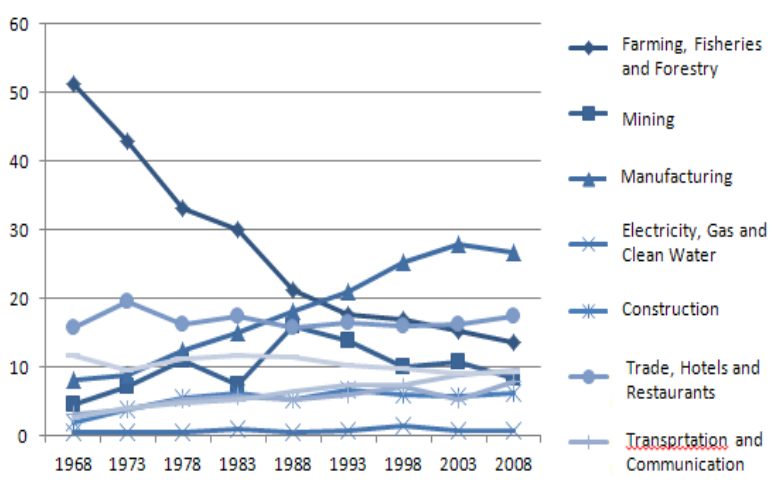

Figure 2. The industrial sectors' percentage of Product Domestic Bruto

Table 2. Sample taken in this research $(n=320)$

\begin{tabular}{crrrrrrr}
\hline & Banten & DKI & \multicolumn{2}{c}{ Jabar Jateng } & DIY & Jatim \\
\hline Wood (186) & 11 & 4 & 25 & 60 & 28 & 58 \\
Small Ent. & 10 & 3 & 22 & 52 & 24 & 51 \\
Medium Ent. & 1 & 1 & 3 & 8 & 4 & 7 \\
Metal (134) & 6 & 10 & 43 & 32 & 0 & 43 \\
Small Ent. & 5 & 9 & 38 & 28 & 0 & 38 \\
Medium Ent. & 1 & 1 & 5 & 4 & 0 & 5 \\
\hline
\end{tabular}

Source: calculated based on (Kemenperin[39]) hierarchical methods. Ward's method is used to find the initial number of clusters and the reason for the clusters formation through agglomeration schedule. With this method, the initial number of clusters is five. The second step is a cluster analysis that uses the k-means method. K-means method is a cluster analysis technique that is used when the analyst has an initial hypothesis of the number of clusters.

Based on the supplier side score, customer side score and internal side score, cluster analysis is conducted to group the SMEs. This means the SMEs are grouped based on their business proceses that are already supported by IT and each group represents an e-business initiative of Indonesia SMEs.

The cluster analysis groups the SMEs into five clusters (Table 3). The first cluster consists of 155 companies that have implemented e-business in the three business focuses, but without focus on any side of business focuses. With 4.46 global score, SMEs in this cluster have assimilated $4.46 \%$ of total ebusiness knowledge and skill. It means that this group is in the early phase of e-business adoption in their company.

In the second cluster ( $\mathrm{n}=19$ ), SMEs focus on internal business processes. The internal side score (42.64) of this cluster is higher than its supplier side score (3.20) and customer side score (5.43). There is closeness between the global score of the second group (14.74) and the third group (13.94), but both have different focuses. The second cluster focuses on internal side and the third cluster focuses on customer side. The third cluster $(n=58)$ has customer side score (27.78) which is higher than supplier side score (6.70) and internal side (5.53).

The fourth cluster $(n=31)$ is different from the three previous groups, that SMEs in this cluster implement e-business which focuses on the internal side and the customer side. This cluster encourages more strongly e-business implementation on internal side (its score $=43.34$ ) and customer side (its score = 24.64) than supplier side (its score $=5.95$ ).

The fifth cluster $(n=57)$ is a group of SMEs that advance their e-business implementation on the three sides of business focuses. This cluster assimilates IT knowledge and skill in supplier side by $22.04 \%$, in internal side by $43.34 \%$ and in customer side by $44.48 \%$. Globally, the SMEs in this most advanced cluster assimilate the knowledge and skill of IT by $33.85 \%$.

Based on these clusters, there are five e-business initiatives in Indonesian manufacturing SMEs. These five initiatives are: (1) the implementation of 
e-business in the three side of business focuses but lack of any focuses, (2) the implementation of ebusiness that focuses on internal side, (3) the customer focus e-business initiative, (4) the initiative that focuses on internal side and customers side, and (5) the balanced initiatives that the three side of business focuses have an extended support by ebusiness.

\section{Cluster Validation}

In Table 3, the clusters are formed significantly different $(p=0)$. However, we need to know whether the SME grouping is valid or not. This study uses discriminant analysis to validate the results of cluster analysis. Table 4 presents the result of dicriminant analysis. The first cluster has 150 SMEs (96.80\%) that are correctly grouped and only 5 SMEs $(3.20 \%)$ should be in the fourth cluster. The fourth cluster has 28 SMEs $(90.30 \%)$ that are correctly grouped and only $3(9.70 \%)$ which is supposed to be in cluster 2. The SMEs in the second cluster, the third cluster and the fifth cluster are perfectly classified. Totally, 97.5\% of SMEs have been grouped correctly. Based on these results, the clusters of SMEs that is based on their e-business initiatives in Indonesian manufacturing SMEs are valid.

\section{The Relationship between E-business Initia- tives and Business Processes}

Table 5 presents the business processes which are dominantly run electronically within each e-business initiative. This table also shows that, since the business focuses. But, from the functional activities perspectives, all initiatives have not implemented ebusiness in the productions/operations (business processes 15 to 21 in Figure 1) and distributions/ logistics area (33 to 36), because this quantitative study does not find any business processes in both area that are supported by e-business.

In previous study (Saptadi et al. [33]), there is one SME that implemented e-business in production activity. This SME has business process 17 supported by a tool management software in order to minimize the tools cost. From these two studies, the implementation of e-business in production activities is rare among SMEs and this business process can be ignored for further analysis.

In product design and engineering activities (1 to 5), business processes 4 and 5 are not listed in Table 5 . This means Indonesian manufacturing SMEs have not implemented e-business to support the collaboration between SMEs and their partners (suppliers and customers). It does not mean that SMEs do not collaborate with their suppliers and customers at all, but these collaborative engineering processes have not been executed electronically.

By comparing the implementation of e-business in procurement/purchasing activities (6 to 14) and selling/marketing (22 to 32), SMEs have more focus on customer relationship than supplier. There are nine of eleven business processes in selling/ marketing activities and only three of nine business processes in procurement/purchasing that are supported by e-business. From both activities, SMEs do not sell their products and buy their material using electronic auctions and tender.

Table 5 also shows that a higher initiative includes business processes that are already supported by ebusiness in a lower initiative. As an example,

Table 3. The e-business initiatives: the results of cluster analysis $(n=320)$

\begin{tabular}{|c|c|c|c|c|c|c|}
\hline & Cluster 1 & Cluster 2 & Cluster 3 & Cluster 4 & Cluster 5 & \\
\hline E-business initiatives & $\begin{array}{l}\text { Early Stage } \\
\quad(\mathrm{n}=155)\end{array}$ & $\begin{array}{c}\text { Internal Focus } \\
(\mathrm{n}=19)\end{array}$ & $\begin{array}{l}\text { Customer Focus } \\
(n=58)\end{array}$ & $\begin{array}{c}\text { Internal and Customer } \\
\text { focus ( } \mathrm{n}=31)\end{array}$ & $\begin{array}{c}\text { Balanced Focus } \\
(\mathrm{n}=57)\end{array}$ & $\mathrm{p}^{\mathrm{a}}$ \\
\hline Supplier side score ${ }^{b}$ & 2.63 & 2.20 & 6.70 & 5.95 & 22.04 & 0.000 \\
\hline Internal side score ${ }^{b}$ & 5.49 & 42.64 & 5.53 & 43.34 & 43.34 & 0.000 \\
\hline Customer side score $^{b}$ & 4.94 & 5.43 & 27.78 & 24.64 & 44.48 & 0.000 \\
\hline Global score $^{b}$ & 4.46 & 14.74 & 13.94 & 23.91 & 33.85 & 0.000 \\
\hline
\end{tabular}

a $\mathrm{p}=$ significance level of ANOVA test

${ }^{\mathrm{b}}$ maximum score $=100$ and minimum score $=0$. These scores represents the weighted sum.

Table 4. Validation of the five clusters

\begin{tabular}{|c|c|c|c|c|c|}
\hline \multirow{2}{*}{ Actual Membership } & \multicolumn{5}{|c|}{ PredITed membership } \\
\hline & Cluster $1(\mathrm{n}=150)$ & Cluster $2(\mathrm{n}=19)$ & Cluster $3(\mathrm{n}=58)$ & Cluster $4(\mathrm{n}=28)$ & Cluster $5(\mathrm{n}=57)$ \\
\hline Cluster $1(\mathrm{n}=155)$ & $96,80 \%$ & & & $3,20 \%$ & \\
\hline Cluster $2(\mathrm{n}=19)$ & & $100 \%$ & & & \\
\hline Cluster $3(n=58)$ & & & $100,00 \%$ & & \\
\hline Cluster $4(\mathrm{n}=31)$ & & $9,70 \%$ & & $90,30 \%$ & \\
\hline Cluster 5 (57) & & & & & $100 \%$ \\
\hline
\end{tabular}

97,5\% SMEs have been grouped correctly 
customer focus (cluster 3 ), that is a higher initiative than early stage (cluster 1). This customer focus initiative has implemented e-business on early stage's busines processes $(6,7,22,23$ and 24) with additional business processes $(1,3,25,29,31$ and $32)$.

\section{The Relationship between E-business Initia- tives and Business Characteristics}

Table 6 presents the number of wood and metal manufacturing SMEs in each initiative with their business characteristics. SMEs that work in wood manufacturing have e-business initiatives that rely on the characteristic of their products and their market orientation. This can be understood by looking at the differences between SMEs in clusters 1, 2 and 3 and SMEs in clusters 4 and 5. Wood manufacturing SMEs with product characteristics in the form of finished products have higher e-business initiatives than the SMEs that produce components and semi-finished products (components and product assemblies before finishing). According to the market orientation, export-oriented SMEs have higher ebusiness initiatives than the SMEs that sell the products to the local or national companies.
In metal manufacturing SMEs, product characteristics and market orientation are not the differentiators among the initiatives. The differentiator among the e-business initiatives of metal manufacturing SMEs is the size of company. Metal manufacturing medium enterprises has e-business initiatives which are higher than the small enterprises. This is evident from the cluster 4 and cluster 5 which contains metal manufacturing medium enterprises. For wood manufacturing SMEs, there is a mix between SEs and MEs in cluster 5 and the MEs only show up in this cluster.

This study classifies the product orders into by-order and by-contract. Both types of orders essentially are by order and all SMEs in this study are B2B manufacturing SMEs. By-contract order is defined as an order with a longer term than by-order, with a written contract between SMEs and their customers. This means by-contract order is a continuous order during the contract. All wood manufacturing SMEs work based on by order. It means this study does not find any wood manufacturing SMEs that work based on a longer term contract.

Table 5. The relationship between initiatives and business processes

\begin{tabular}{|c|c|c|c|}
\hline Initiatives & Supplier & Internal & Customer \\
\hline $\begin{array}{l}\text { Cluster 1-early } \\
\text { stage }\left(155^{*}\right)\end{array}$ & $\begin{array}{l}\text { 6. Seek out new suppliers }\left(118^{* *}\right) \\
\text { 7. Seek out products/services }(121)\end{array}$ & $\begin{array}{l}\text { 24. Convert information on } \\
\text { products/services into digital } \\
\text { form (155) }\end{array}$ & $\begin{array}{l}\text { 22. Advertise the company and/or its } \\
\text { products/services (155) } \\
\text { 23. Seek out new customers (147) }\end{array}$ \\
\hline $\begin{array}{l}\text { Cluster 2-internal } \\
\text { focus (19) }\end{array}$ & Same as cluster 1 & $\begin{array}{l}\text { Same as cluster } 1 \\
\text { 37. Administrate business } \\
\text { transcations (19) } \\
\text { 38. Administrate debt (19) } \\
\text { 39. Administrate receivables (19) } \\
\text { 40. Account profit/loss (19) } \\
\text { 41. Account the assets (19) }\end{array}$ & Same as cluster 1 \\
\hline $\begin{array}{l}\text { Cluster 3-customer } \\
\text { focus (58) }\end{array}$ & Same as cluster 1 & Same as cluster 1 & $\begin{array}{l}\text { Same as cluster } 1 \\
\text { 1. Transfer documents and technical } \\
\text { drawings to customers (58) } \\
\text { 3. Integrate software supporting product } \\
\text { design (e.g.: CAD/CAM) (58) } \\
\text { 25. Sell products/services using electronic } \\
\text { catalogs (48) } \\
\text { 29. Receive and manage customer orders (48) } \\
\text { 31. Access customers' product/service } \\
\text { databases (48) } \\
\text { 32. Offer customers after-sales services (49) }\end{array}$ \\
\hline
\end{tabular}

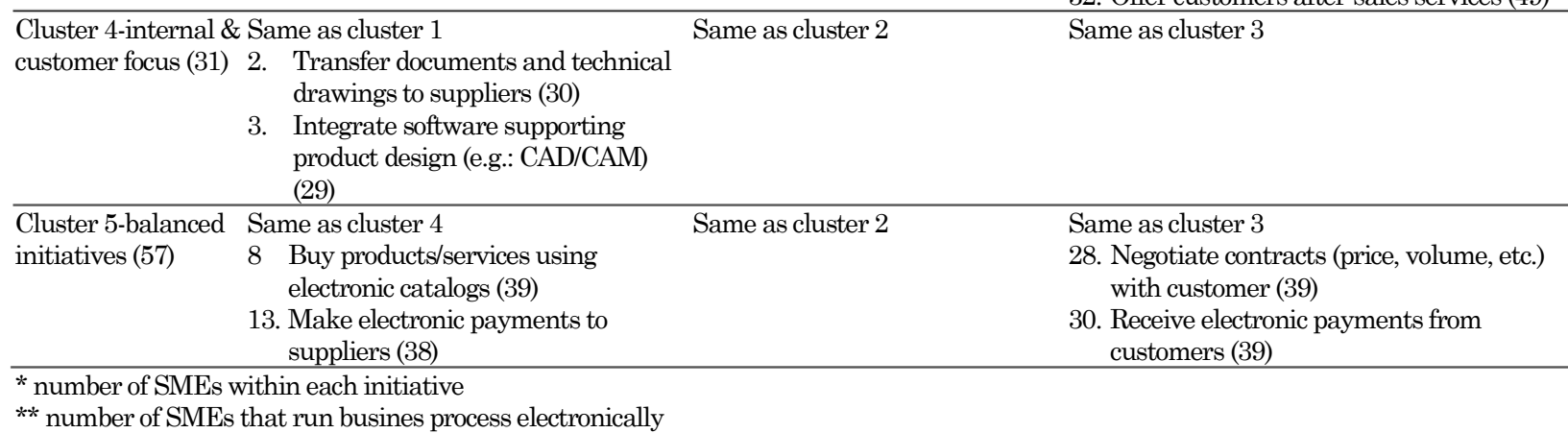


Tabel 6. Business characteristics in each e-business initiative

\begin{tabular}{|c|c|c|c|c|c|c|}
\hline Material & $\begin{array}{c}\text { Business } \\
\text { Characteristics }\end{array}$ & 1-early stage & 2-internal focus & 3-customer focus & $\begin{array}{l}\text { 4-internal \& } \\
\text { customer focus }\end{array}$ & 5-balanced focus \\
\hline \multirow{5}{*}{ Wood } & $\begin{array}{l}\text { Number of } \\
\text { companies }\end{array}$ & $81 \mathrm{SE}$ & $10 \mathrm{SE}$ & $23 \mathrm{SE}$ & $29 \mathrm{SE}$ & $19 \mathrm{SE}, 24 \mathrm{ME}^{*}$ \\
\hline & $\begin{array}{l}\text { Product } \\
\text { Characteristic }\end{array}$ & $\begin{array}{l}\text { Semi-finished } \\
\text { product and } \\
\text { Spare part }\end{array}$ & $\begin{array}{l}\text { Semi-finished } \\
\text { product and } \\
\text { Spare part }\end{array}$ & $\begin{array}{l}\text { Semi-finished } \\
\text { product }\end{array}$ & Finished product & Finished product \\
\hline & Order & By order & By order & By or & By order & by order \\
\hline & Customer & Manufacturing & Manufacturing & Manufacturing & Retailer & Retailer \\
\hline & Market & Local & Local & National & $\begin{array}{l}\text { National-- } \\
\text { International }\end{array}$ & $\begin{array}{l}\text { National- } \\
\text { International }\end{array}$ \\
\hline \multirow{5}{*}{ Metal } & $\begin{array}{l}\text { Number of } \\
\text { companies }\end{array}$ & $74 \mathrm{SE}$ & $9 \mathrm{SE}$ & $35 \mathrm{SE}$ & $2 \mathrm{ME}$ & $14 \mathrm{ME}$ \\
\hline & $\begin{array}{l}\text { Product } \\
\text { Characteristic }\end{array}$ & Sparepart & Sparepart & Sparepart & Sparepart & Sparepart \\
\hline & Order** & $\begin{array}{l}\text { By contract } \\
\text { By order }\end{array}$ & $\begin{array}{l}\text { By contract \& By } \\
\text { order }\end{array}$ & $\begin{array}{l}\text { By contract \& By } \\
\text { order }\end{array}$ & By contract & By contract \\
\hline & Customer & $\begin{array}{l}\text { Manufacturing \& } \\
\text { retailer }\end{array}$ & $\begin{array}{l}\text { Manufacturing \& } \\
\text { retailer }\end{array}$ & $\begin{array}{l}\text { Manufacturing \& } \\
\text { retailer }\end{array}$ & $\begin{array}{l}\text { Manufacturing \& } \\
\text { retailer }\end{array}$ & $\begin{array}{l}\text { Manufacturing \& } \\
\text { retailer }\end{array}$ \\
\hline & Market & National & National & National & National & National \\
\hline
\end{tabular}

* $\mathrm{SE}=$ small enterprises; $\mathrm{ME}=$ medium enterprises

** By contract order is a longer term order than by order, with a written contract between SMEs and their customers

This study suggests that wood-based SMEs that implement the lower e-business initiatives (in clusters 1,2 and 3) are the suppliers of components or semi-finished products for SMEs that implement the higher initiatives (in clusters 4 and 5). Semifinished products and components that are produced by SMEs in the three clusters 1, 2 and 3 are sent to the SMEs in cluster 4 and 5 to be finished and assembled. After finishing and assembly, the products are sent to the national and international retailers.

All metal manufacturing SMEs are not the producer of end-products. They produce spare-parts that supply other manufacturing companies. Different from the orders of wood manufacturing SMEs, metal manufacturing SMEs work based on contract and order. Metal manufacturing SMEs, that implement higher e-business initiative, focus more on a longer term order (by-contract than by-order). This is evident from SMEs in clusters 4 and 5 .

This study suggests that a bigger company have a higher e-business initiative. Although some studies proved that company size did not influence ebusiness initiatives (Gutierrez et al. [41]; Levy and Powell, [30,42]), this study supports some previous studies that showed that company size is an important factor for e-business initiatives (Acar et al. [43]; Wymer and Regan [43]).

\section{Conclusion}

This study finds five e-business initiatives in Indonesian manufacturing SMEs. These five initia- tives are: (1) the implementation of e-business in the three side of business focus but lack of any focuses, (2) the implementation of e-business that focuses on internal side, (3) the customer focus e-business initiative, (4) the initiative that focuses on internal side and customers side, and (5) the balanced initiative that three side of business focuses have extended support by e-business. In Indonesian manufacturing SMEs, customer relationship and internal efficiency have higher priority to be supported by e-business than supplier relationship.

There are some differences batween the e-business iniatives among Indonesian manufacturing SMEs and Canadian manufacturing SMEs. There are four e-business intitiatives among Canadian manufacturing SMEs. First iniative is e-business implementation in three sides of business focuses with lack of any focuses. Second initiative is e-business that focuses on supplier side. Third initiative is e-business implementation that focuses on customer side. The last is an initiative that leverages the supplier side and the customer side. In Canadian manufacturing SMEs, customer relationship and supplier relationship have higher priority to be supported by ebusiness than internal efficiency.

Because, this study finds that a higher e-business initiative is a lower initiative plus other business processes that are supported by e-business, then five e-business initiatives are suspected to be an evolutionary development of e-business initiatives in Indonesian manufacturing SMEs. However, to ensure these findings, further elaboration must be conducted in the next research. 
There are some differences among SMEs in each business initiatives. This study shows that the company size is a differentiator for the wood and metal manufacturing SMEs. This is indicated by the presence of medium enterprises in clusters 4 and 5. Beside the company size, the differentiators among initiatives in wood manufacturing are the product characteristics, the type of customer, and the market orientation. In metal manufacturing SMEs, beside the company size, the type of order is also a differentiator among the SMEs.

Since this paper is a part of the research on the development of business-IT alignment framework, there are some further researches to be done. Further researches are needed to understand what benefits are gained by the SMEs according to their ebusiness initiatives, what motivates SMEs to implement the initiatives and what factors that influence the business-IT alignment in manufacturing SMEs.

\section{References}

1. Indonesia, P. R., Undang-Undang Republik Indonesia Nomor 20 tahun 2008 tentang Usaha Mikro, Kecil dan Menengah, Jakarta, 2008.

2. Depkopukm, Perkembangan Data Usaha Mikro, Kecil, Menengah (UMKM) dan Usaha Besar (UB) Tahun 2008 s.d. 2009, Jakarta: Departemen Koperasi dan Usaha Kecil dan Menengah Republik Indonesia, 2010.

3. Lefebvre, L. A., Lefebvre, E., and Mohnen, P., Doing Business in the Knowledge-Based Economy: Facts and Policy Challenges, Kluwer, New York, 2001.

4. Hamad, H. S., Antecedents of Business-to-Business e-Commerce Adoption and its Effect on Competitive Advantage in Manufacturing Small and Medium-sized Enterprises: A Comparative Study of United States of America and Egypt, Faculty of Business, Plymouth University, Doctor of Philosophy, 2014.

5. Alam, S. S., and Noor, M. K. M., IT Adoption in Small and Medium Enterprises: An Empirical Evidence of Service Sectors in Malaysia, International Journal of Business and Management, 4(2), 2009, pp. 112-125.

6. Porter, M. E., Strategy and the Internet, Harvard Business Review, 2001.

7. Laudon, K. C., and Laudon, J. P., Esssentials of Management Information Systems: Organization and Technology in Networked Enterprise: Prentice-Hall, 2001.

8. Avlonitis, G. J., and Karayanni, D. A., The Impact of Internet Use on Business-to-Business Marketing: Examples from American and Euro- pean Companies. Industrial Marketing Management, 29, 2000, pp. 441-459.

9. Gilmore, A., Gallagher, D., and Henry, S., Emarketing and SMEs: Operational Lessons for the Future, European Business Review, 19(3), 2007, pp. 234-247

10. Beach, R., Adopting Internet Technology in Manufacturing: A Strategic Perspective, Production Planning \& Control, 15(1), 2004, pp. 80-89.

11. Goode, S., and Stevens, K., An Analysis of the Business Characteristics of Adopters and NonAdopters of World Wide Web Technology, Information Technology and Management, 1, 2000, pp. 129-154.

12. Moriones, A. B., and Lopez, F. L., A Firm-Level Analysis of Determinants of ICT Adoption in Spain, Technovation, 27(6-7), 2007, pp. 352-366.

13. Saptadi, S., Govindaraju, R., Samadi, T. A., and Sudirman, I., Internet Adoption and BusinessInformation Technology Alignment in Indonesia SMEs: A Literature Review, Paper Presented at the International Seminar on Business and Management, Bandung, Indonesia, 2011.

14. Saptadi, S., Sudirman, I., Samadhi, T. A., and Govindaraju, R., Business - IT Alignment Success Framework for Manufacturing SMEs (A Conceptual Model), Paper Presented at the $6^{\text {th }}$ IEEE International Conference on Management of Innovation and Technology, Bali, Indonesia, 2012.

15. Wahid, F., and Iswari, L., Adopsi Teknologi Informasi oleh Usaha Kecil Menengah di Indonesia, Paper Presented at the National Seminar on Application of Information Technology, Yogyakarta, 2007.

16. Roosdhani, M. R., Wibowo, P. A., and Widiastuti, A., Analisis Tingkat Penggunaan Teknologi Informasi dan Komunikasi pada Usaha Kecil Menengah di Kabupaten Jepara, Jurnal Dinamika Ekonomi \& Bisnis, 9, 2012, pp. 89-104

17. Smecda, Strategi Peningkatan Kemampuan Adopsi Teknologi Informasi untuk Meningkatkan Daya Saing UKM, Retrieved 10 January, 2011, from http://www.smecda.com/Files/infosmecda/misc/Strategi_Peningkatan_kemampuan. pdf.

18. Tallon, P. P., Kraemer, K. L., and Gurbaxani, V., Executives' Perceptions of the Business Value of Information Technology, A Process-oriented Approach, Journal of Management Information Systems, 16(4), 2001, pp. 145-173.

19. Rivard, S., Raymond, L., and Verreault, D., Resource-based View and Competitive Strategy: An Integrated Model of the Contribution of Information Technology to Firm Performance, Strategic Informations Systems, 15(1), 2006, pp. 29-50. 
20. Kohli, R., and Grover, V., Business Value of IT: An Essay on Expanding Research Directions to Keep Up with the Times, Journal of the Association for Information Systems, 9(2), 2008, pp. 23-39.

21. Zhu, K., and Kraemer, K. L., e-Commerce Metrics for Net-Enhanced Organizations: Assessing the Value of e-Commerce to Firm Performance in the Manufacturing Sector, Information Systems Research, 13(3), 2002, pp. 275-295.

22. Brynjolfsson, E., and Yang, S., Information Technology and Productivity: A Review of the Literature, Advances in Computers, 43, 1996, pp. 179-214.

23. Ramdani, B., Information Technology and Organisational Performance: Reviewing the Business Value of IT Literature, In Y. K. Dwivedi, M. R. Wade \& S. L. Schneberger (Eds.), Information Systems Theory: Explaining and Predicting Our Digital Society, 1, 2012. New York: Springer.

24. Kauffman, R. J., and Weill, P., An Evaluative Framework for Research on the Performance Effects of Information Technology Investment, Paper presented at the Tenth International Conference on Information Systems, Boston, Massachusetts, 1989.

25. Barua, A., Kriebel, C. H., and Mukhopadhyay, T., Information Technologies and Business Value: An Analytic and Empirical Investigation, Information Systems Research, 6(1), 1995, pp. 3-21.

26. Zhu, K., and Kraemer, K. L., Post-Adoption Variations in Usage and Value of E-Business by Organizations: Cross-Country Evidence from the Retail Industry, Information Systems Research, 16(1), 2005, pp. 61-84.

27. Dohmen, A., Leyer, M., and Patas, J., Towards a Methodology to Assess Changes in IT Business Value in Terms of Business Process Performance, Paper presented at the Americas Conference on Information Systems, 2010.

28. Earl, M., Evolving the E-Business, Business Strategy Review, 11(2), 2000,pp. 33-38.

29. Magal, S. R., Feng, M., and Essex, P. A., An Exploratory Study of Web-Based Electronic Commerce Applications, The Journal of Information Technology Theory and Application, 3(5), 2001, pp. 1-24.

30. Levy, M., and Powell, P., Strategies for Growth in SMEs: The Role of Information and Information Systems, Elsevier, Amsterdam, 2005.

31. Sahin, I., Detailed Review of Roger's Diffusion of Innovations: Theory and Educational Technology-Related Studies Based on Roger's Theory, The Turkish Online Journal of Educational Technology, 5(2), 2006, pp. 14-23.
32. Elia, E., Lefebvre, L. A., and Lefebvre, É., Focus of B-to-B E-commerce Initiatives and Related Benefits in Manufacturing Small- and MediumSized Enterprises, Information Systems and $e$ Business Management, 5(1), 2007, pp. 1-23.

33. Saptadi, S., Sudirman, I., Samadhi, T. M. A. A., and Govindaraju, R., Studi Kualitatif Implementasi E- Business di UKM Manufaktur Indonesia, Paper Presented at the Seminar Nasional $5^{\text {th }}$ Indisco, Semarang, 2013.

34. BPS, Berita Resmi Statistik - Perkembangan Indikator Makro UKM Tahun 2009, Jakarta: Biro Pusat Statistik, 2009.

35. Hair, J. F., Black, W. C., Babin, B. J., and Anderson, R. E., Multivariate Data Analysis: Prentice Hall, 2009.

36. Dolnicar, S., A Review of Unquestioned Standards in Using Cluster Analysis for Data-Driven Market Segmentation, Paper Presented at the Australian and New Zealand Marketing Academy Conference 2002 (ANZMAC 2002), Deakin University, Melbourne.

37. Mooi, E., and Sarstedt, M., A Concise Guide to Market Research, Berlin Heidelberg: SpringerVerlag., 2011.

38. Tanjung, C., Ekonomi Kesejahteraan sebagai Penggerak Ekonomi Indonesia Menuju Pentas Dunia, Retrieved 11 December, 2013, from http://www.academia.edu/4234933/Kuliah_Umum_ Bp._CT

39. Kemenperin, Direktori Perusahaan. Retrieved 22 November, 2012, from http://www.Kemen perin.go.id/direktori-perusahaan.

40. Burns, R. B., and Burns, R. A., Business Research Methods and Statistics Using SPSS: Sage Publications Ltd, 2008.

41. Gutierrez, A., Orozco, A. N., Serrano, A., and Yazdouni, H., Comparing Alignment Factors in SMEs and Large Organizations: A Planning Integration Perspective, Paper presented at the Americas Conference of Information Systems, Keystone, Colorado, 2007.

42. Levy, M., and Powell, P., Exploring SME Internet Adoption: Towards a Contingent Model, Electronic Markets, 13(2), 2003, pp. 173-181.

43. Acar, E., Kocak, I., Sey, Y., and Arditi, D., Use of Information and Communication Technologies by Small and Medium-Sized Enterprises (SMEs) in Building Construction, Construction Management and Economics, 23, 2005, pp. 713-722.

44. Wymer, S., and Regan, E., Factors Influencing ECommerce Adoption and Use by Small and Medium Businesses, Electronic Markets - The International Journal, 15(4), 2005, pp. 438-453. 